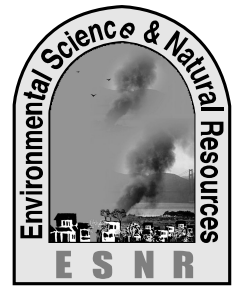

J. Environ. Sci. \& Natural Resources, 5(1): 55-59, 2012

ISSN 1999-7361

\title{
Effect of Arsenic Amended Irrigation Water on Growth and Yield of BR-11 Rice (Oryza sativa L.) Grown in Open Field Gangetic Soil Condition in Rajshahi
}

\author{
M. A. K. Azad ${ }^{1}$, A. H. M. F. K. Mondal ${ }^{1}$, M. I. Hossain ${ }^{2}$ and M. Moniruzzaman ${ }^{3}$ \\ ${ }^{1}$ Institute of Environmental Science, Rajshahi University, Rajshahi \\ ${ }^{2}$ Dept. of Geology \& Mining, Rajshahi University, Rajshahi \\ ${ }^{3}$ Dept. of Geography \& Environmental Studies, Rajshahi University, Rajshahi
}

\begin{abstract}
Rice was grown in an open-field Gangetic soil condition with arsenic amended irrigation water in experimental plot at Institute of Environmental Science of Rajshahi University to see the effect of arsenic (As) on growth and yield of rice (Oryza sativa L.). A popular aman rice variety named BR-11 was cultivated with arsenic amended irrigation water $(0 \mathrm{mg}, 0.1 \mathrm{mg}, 0.5 \mathrm{mg}, 1.0 \mathrm{mg}, 2.0$ $\mathrm{mg}$ and $4.0 \mathrm{mg} / \mathrm{L} \mathrm{As}$ containing water) in a green house made of transparent poly-ethylene paper. Sodium arsenate $\left(\mathrm{Na}_{2} \mathrm{HAsO}\right)_{4}$ was added to irrigation water for arsenic source. The tillers number, panicle length and grain yield of BR-11 rice were found to decrease significantly $(\mathrm{p} \leq 0.05)$ with increase of arsenic (As) concentration in irrigation water. The highest values of plant height and straw yield was observed in $0.5 \mathrm{mgL}^{-1}$ treatment, whereas highest tillers number, panicles number, panicle length and grain yield were found in control treatment. The lowest values of these parameters were observed in the treatment of $4.0 \mathrm{mgL}^{-1} \mathrm{As}$ containing irrigation water.
\end{abstract}

Key Words: Arsenic, Grain, Rice, Straw

\section{Introduction}

In Bangladesh, arsenic contamination of groundwater was confirmed in 1993 (British Geological Survey, 2000). Much of the shallow groundwater in southern Bangladesh and the eastern part of West Bengal, India, is naturally contaminated with As (BGS and DPHE, 2001), exposing more than 40 million people to unsafe levels of As in drinking water (Smith et al. 2000; World Bank, 2005). Arsenic contamination potentially threatening food security as As can be toxic to rice (Marin et al. 1992; Yan et al. 2005). Widespread arsenic (As) pollution of shallow tube well (STW) irrigation water and increasing accumulation of As in soils have become a major threat to rice production. Rice is the staple food of Bangladesh (Hossain et al. 2008; Panaullah et al. 2009). About $70 \%$ of the total arable land area is currently irrigated from shallow tube wells (BGS and DPHE, 2001). Arsenic contaminated irrigation water has been shown to lead to elevated levels of As in paddy soil and soil solution (Meharg and Rahman 2003; Van Geen et al. 2006; Dittmar et al. 2007). Artificially elevated levels of As in irrigation water or soil can reduce growth and productivity of rice (Abedin et al. 2002; Delowar et al. 2005; Islam et al. 2004). Use of high As irrigation water can increase the As level in soil (Hossain et al. 2008; Khan et al. 2009), decrease the rice yields (Jahiruddin et al. 2004; Heikens et al. 2007; Panaullah et al. 2009). However, there have been limited research done in open-field gangetic soil condition on effect of arsenic contaminated irrigation water on growth and yield of rice (Oryza sativa L). Thus the present study was conducted to fulfill the following specific objectives:
( a) to observe the impact of irrigation water arsenic on growth and yield of BR-11 rice, (b) to find out the permissible limit of arsenic in irrigation water for rice cultivation.

\section{Materials and Methods}

\section{Experimental Site}

This field experiment was conducted in a green house made of transparent poly-ethylene paper at Institute of Environmental Science of Rajshahi University located in north-western part of Bangladesh during August to December 2011. The study site has subtropical and humid climate with adequate sunshine during day time.

\section{Soil condition}

The experiment was conducted in Gangetic soil condition. The properties of soil were total Nitrogen $0.04 \pm 0.02 \%$, available P $25.3 \pm 0.04 \mathrm{ppm}$, available K $0.21 \pm 0.03 \mathrm{~mol} / \mathrm{kg}$, available $\mathrm{S} \quad 15.7 \pm 0.05 \mathrm{ppm}$, available $\mathrm{Z} 0.68 \pm 0.04 \mathrm{ppm}, \mathrm{pH} 7.7 \pm 0.03$, organic matter $0.80 \pm 0.05$ and background total arsenic (As) $5.60 \pm 0.05 \mathrm{ppm}$.

\section{Rice variety}

Rice variety, BR-11 is very popular aman variety in Bangladesh. This rice variety was cultivated for this experiment.

\section{Seedling Transplantation}

Thirty-five days old seedlings were uprooted carefully from the seedbed in the morning from the Bangladesh Rice Research Institute, Rajshahi station and four seedlings for each hill with three replications were transplanted on the same day in experimental field on $7^{\text {th }}$ August 2011. The seedlings which died 
within 6 days of transplantation were discarded and new seedlings were replaced.

\section{Intercultural application}

\section{a) Fertilizer application}

To support the plant growth, urea, triple super phosphate (TSP), murate of potash (MP) and gypsum fertilizer were applied for nitrogen, phosphorus, potassium, and sulfur, respectively. The first spilt (one third of the dose) of urea and full doses of all other fertilizers were incorporated into the soil by hand before two days of seedling transplantation. The second and third splits of urea were applied after 30 (maximum tillering stage) and 70 (panicle initiation stage) days of transplantation, respectively. One insecticide named fighter was applied into the soil to kill the insects and aphids those attacked the rice plants.

\section{b) Arsenic source}

Sodium arsenate $\left(\mathrm{Na}_{2} \mathrm{HAsO}_{4}\right)$ was used for arsenic source.

\section{c) Irrigation and Treatment}

Six arsenic treatments $0.0,0.1,0.5,1.0,2.0$, and 4.0 $\mathrm{mg} / \mathrm{L}$ As containing irrigation water were used in this experiment. After transplantation of rice seedlings, 3$4 \mathrm{~cm}$ water above soil level was maintained in each treatment throughout the growth period. Irrigation was stopped before 10 days of harvest.

\section{d) Sample collection and preservation}

The rice plants were cut at $4 \mathrm{~cm}$ above the soil. Rice grain was harvested at their maturity stage (120 days after transplantation) on $7^{\text {th }}$ December 2011. Then the collected samples (straw and rice grain) from each treatment were tagged properly and sun dried for 3 days and then keeping the samples on a wooden table. The sun dried samples were stored in a drying cabinet at $45^{\circ} \mathrm{C}$. Before taking the final weight, all samples were oven dried at $65^{\circ} \mathrm{C}$ for 72 hour.

\section{e) Statistical analysis}

The analysis of variance (ANOVA) for rice growth and yield parameters of BR-11 rice were done for least significance difference (LSD). Duncan's multiple range test (DMRT) was used for mean comparisons of the treatment at $5 \%$ level.

\section{Results and Discussion}

\section{a) Effect of arsenic amended irrigation water on growth of $\mathrm{BR}-11$ rice}

\section{Plant height}

Azad et al. (2009) found that arsenic (As) had a significant $(p \leq 0.5)$ effect on the reduction of plant height of T-aman rice. We found that plant height was increased up to the application of $0.5 \mathrm{mgL}^{-1}$ arsenic and thereafter at higher concentration of arsenic had caused a gradual decrease of plant height. Xie and Huang (1994) also reported that lower concentration of arsenic through irrigation water had stimulatory effect for rice. The tallest $(96.64 \pm 0.73 \mathrm{~cm})$ and smallest $(82.66 \pm 7.6 \mathrm{~cm})$ plant height were found in 0.5 and $4.0 \mathrm{mgL}^{-1}$ arsenic amended plots (Table-1). This study found a negative correlation $\left(\mathrm{r}^{2}=0.818\right)$ between arsenic in irrigation water and plant height. Abedin et al. (2002) also found that arsenic contaminated irrigation water significantly reduced the plant height.

Table 1. Effect of arsenic amended irrigation water on growth of BR-11 rice

\begin{tabular}{|c|c|c|c|c|c|}
\hline $\begin{array}{c}\text { Arsenic added in } \\
\text { water (mg/L) }\end{array}$ & Plant height (cm) & $\begin{array}{c}\text { Tillers/Plant } \\
(\text { no. })\end{array}$ & $\begin{array}{c}\text { Panicles/Plant } \\
(\text { no. })\end{array}$ & $\begin{array}{c}\text { Panicle length } \\
(\mathrm{cm})\end{array}$ & $\begin{array}{c}1000 \text {-grain weight } \\
(\mathrm{g})\end{array}$ \\
\hline 0 & $95.35 \pm 1.78 \mathrm{a}$ & $24.00 \mathrm{a}$ & $16.00 \pm 0.02 \mathrm{a}$ & $24.20 \pm 0.69 \mathrm{a}$ & $18.84 \pm 0.94 \mathrm{a}$ \\
\hline 0.1 & $91.17 \pm 2.00 \mathrm{a}$ & $18.33 \mathrm{ab}$ & $10.67 \pm 3.18 \mathrm{a}$ & $22.80 \pm 0.50 \mathrm{ab}$ & $17.81 \pm 0.06 \mathrm{a}$ \\
\hline 0.5 & $96.64 \pm 0.73 \mathrm{a}$ & $20.67 \mathrm{ab}$ & $15.67 \pm 0.67 \mathrm{a}$ & $22.37 \pm 0.67 \mathrm{ab}$ & $14.21 \pm 1.14 \mathrm{a}$ \\
\hline 1.0 & $92.85 \pm 2.13 \mathrm{a}$ & $17.67 \mathrm{ab}$ & $13.33 \pm 1.45 \mathrm{a}$ & $22.20 \pm 0.25 \mathrm{ab}$ & $13.90 \pm 1.81 \mathrm{a}$ \\
\hline 2.0 & $88.29 \pm 6.17 \mathrm{a}$ & $16.00 \mathrm{~b}$ & $9.67 \pm 2.33 \mathrm{a}$ & $22.10 \pm 0.58 \mathrm{~b}$ & $13.68 \pm 2.14 \mathrm{a}$ \\
\hline 4.0 & $82.66 \pm 7.61 \mathrm{a}$ & $15.00 \mathrm{~b}$ & $9.67 \pm 3.18 \mathrm{a}$ & $21.83 \pm 0.84 \mathrm{~b}$ & $12.50 \pm 5.11 \mathrm{a}$ \\
\hline
\end{tabular}

Values (mean $\pm \mathrm{SE}$ ) without common letters are statistically significant (DMRT, $\mathrm{p} \leq 0.05$ ) 


\section{Tillering}

Chino (1981) reported that tillers of rice to be severely depressed with high concentration of As .We found that arsenic in irrigation water up to $1.0 \mathrm{mg} / \mathrm{L}$ did not affect the tillers number significantly. But a higher concentration of arsenic significantly decreased the total number of tillers per plant. Abedin et al. (2002) also observed that tillers number was reduced significantly with increase of arsenic concentration in irrigation water up to $8 \mathrm{mgL}^{-1}$. The highest number (24.00a) of tillers was observed in control treatment and lowest number (15.00b) was observed in $4.0 \mathrm{mg} / \mathrm{L}$ arsenic treated plot (Table-1). We found a negative correlation $\left(\mathrm{r}^{2}=0.611\right)$ between arsenic in irrigation water and tillers number. Khan et al. (2010) also found that the addition of arsenic significantly reduced tillering.

\section{Panicle number}

Azad et al. (2009) reported that the panicles number of T-aman rice were not affected at low doses of As in soil but significantly affected the panicles number at higher doses. This study found that panicles number was decreased with increase of arsenic concentration in irrigation water but the differences were not statistically significant. The highest panicle number $(16.00 \pm 02 a)$ was observed in control treatment and the lowest panicle number $(9.67 \pm 3.18 \mathrm{a})$ was found in $4.0 \mathrm{mgL}^{-1}$ treatment (Table 1). Arsenic in irrigation water and panicle number had negative relation.

\section{Panicle length}

The panicles length were not affected significantly up to $1.0 \mathrm{mgL}^{-1}$ arsenic treatment, but thereafter the panicles length were decreased significantly $(p \leq 0.5)$ with increase of arsenic in irrigation water. Azad et al. (2009) also found that the panicles length of T-aman rice were not affected at low doses of As in soil but affected significantly at higher doses of As. The highest panicle length $(24.20 \pm 0.69 \mathrm{~cm}$ a) and the lowest panicle length $(21.83 \pm 0.84 \mathrm{~cm} \mathrm{~b})$ were observed in control and 4.0 $\mathrm{mgL}^{-1}$ arsenic treated plot, respectively (Table 1). Arsenic in irrigation water and panicles length had a negative correlation $\left(\mathrm{r}^{2}=0.465\right)$.

\section{0 grain weight}

Abedin (2002) found that presence of arsenic as arsenate at a higher concentration in irrigation water significantly reduced $(\mathrm{p}<0.001)$ the 1000 grain weight. We found that thousand grain weights were decreased with increasing of arsenic in irrigation water but the differences were not statistically significant. Tsutsumi (1980) also reported that arsenic could reduced 1000 grain weight. The highest grain weight $(18.84 \pm 0.94 \mathrm{~g})$ and lowest grain weight $(12.5 \pm 5.11 \mathrm{~g})$ were recorded in control and $4.0 \mathrm{mgL}^{-1}$ arsenic treatment plot, respectively (Table 1). Arsenic in irrigation water and thousand grain weight were related antagonistically $\left(r^{2}=0.602\right)$. Wang et al. (2006) also reported that 1000 grain weight was significantly reduced with increased As level in soil treated with two organoarsenic compound $(\mathrm{p}<0.01)$.

\section{b) Effect of arsenic amended irrigation water on yield of $B R-11$ rice}

\section{Grain yield}

Abedin et al. (2002) reported that grain yield was decreased significantly $(p<0.001)$ with increase of arsenic concentration in irrigation water. We found that grain yield of BR-11 rice was decreased significantly with increase of arsenic concentration in irrigation water. There were also some reports of rice grain yield reduction due to As application for rice (Farn et al. 1988; Milan et al. 1988; Gilmour and Wells, 1988; Liu and Gao, 1987; Tsutsumi, $1980)$. The highest grain yield $(23.38 \pm 5.55 \mathrm{~g}$ a) and lowest grain yield $(7.24 \pm 2.3 \mathrm{~g} \mathrm{~b})$ were found in control and $4.0 \mathrm{mgL}^{-1}$ arsenic treated plot, respectively (Table 2). The grain yield was found to decrease drastically by $58.04 \%$ and $69.03 \%$ compared to control in 2.0 and $4.0 \mathrm{mg} / \mathrm{L}$ arsenic treatments, respectively (Table 2). Hossain et al. (2009) also reported that grain yield of rice was decreased as the level of arsenic addition was increased, and the yield was reduced drastically with the $30 \mathrm{mg} \mathrm{Askg}^{-1}$ addition. We found that grain yield and arsenic concentration in irrigation water had a negative correlation $\left(r^{2}=0.485\right)$. Panaullah et al. (2009) also found rice grain was negatively correlated with soil-As concentration $\left(\mathrm{r}^{2}=0.91\right)$. 
Table 2. Effect of arsenic amended irrigation water on yield of BR-11 rice

\begin{tabular}{|c|l|l|l|l|}
\hline $\begin{array}{c}\text { Arsenic added in water } \\
\left(\mathrm{mgL}^{-1}\right)\end{array}$ & \multicolumn{1}{|c|}{ Grain yield $\left(\mathrm{gpl}^{-1}\right)$} & Straw yield $\left(\mathrm{gpl}^{-1}\right)$ & \multicolumn{2}{|c|}{ Percent of yield reduction over control } \\
\cline { 3 - 5 } & & & \multicolumn{1}{|c|}{ Grain } & 0 \\
\hline 0 & $23.38 \pm 5.55 \mathrm{a}$ & $31.50 \pm 4.53 \mathrm{a}$ & 0 & -3.85 \\
\hline 0.1 & $15.28 \pm 1.28 \mathrm{ab}$ & $30.60 \pm 4.29 \mathrm{a}$ & -34.64 & 24.03 \\
\hline 0.5 & $9.84 \pm 1.31 \mathrm{ab}$ & $39.07 \pm 4.08 \mathrm{a}$ & -57.91 & 8.38 \\
\hline 1.0 & $11.06 \pm 6.22 \mathrm{ab}$ & $34.14 \pm 3.17 \mathrm{a}$ & -52.69 & -7.77 \\
\hline 2.0 & $9.81 \pm 4.64 \mathrm{ab}$ & $29.05 \pm 11.52 \mathrm{a}$ & -58.04 & -14.25 \\
\hline 4.0 & $7.24 \pm 2.32 \mathrm{~b}$ & $27.01 \pm 6.74 \mathrm{a}$ & -69.03 & \\
\hline
\end{tabular}

Values (mean $\pm \mathrm{SE}$ ) without common letters are statistically significant (DMRT, $\mathrm{p} \leq 0.05$ )

\section{Straw yield}

Khan et al. (2010) reported that straw yield was decreased significantly with As addition in irrespective of season, year, method and level of As application. We found that the straw yield of BR-11 rice was increased at $0.5 \mathrm{mgL}^{-1}$ arsenic treatment and thereafter straw yield were decreased with increase of arsenic concentration in irrigation water but the differences were not statistically significant. The highest straw yield $(39.07 \pm 4.08 \mathrm{~g}$ a) and lowest straw yield $\left(27.01 \pm 6.74 \mathrm{~g}\right.$ a) were found in $0.5 \mathrm{mgL}^{-1}$ and $4.0 \mathrm{mgL}^{-1}$ arsenic treatment (Table 2). Arsenic concentration in irrigation water and straw yield had a negative correlation $\left(\mathrm{r}^{2}=0.362\right)$. Hossain et al. (2009) also found a negative relationship between straw yield and As dose. The straw yield decreased by $7.77 \%$ and $14.25 \%$ compared to control in $2.0 \mathrm{mg} / \mathrm{L}$ and $4.0 \mathrm{mg} / \mathrm{L}$ arsenic treatments, respectively (Table 2). Abedin et al. (2002) also found that straw yield were significantly $(p<0.001)$ reduced with increase of arsenate concentration in irrigation water.

\section{Conclusions}

Rice growth and yield were significantly affected by arsenic in irrigation water $(\mathrm{p} \leq 0.05)$. Lower concentration of arsenic in irrigation water (up to 0.5 $\mathrm{mgL}^{-1}$ ) stimulated the rice growth and yield but higher concentration of arsenic in irrigation water (above $0.5 \mathrm{mgL}^{-1}$ ) reduced the rice growth and yield markedly. Farmers of Bangladesh should avoid above $0.5 \mathrm{mgL}^{-1}$ arsenic contaminated ground water for irrigation in rice cultivation.

\section{Acknowledgements}

We acknowledge the Ministry of Science and Technology, Government of the Peoples Republic of Bangladesh for financial support as fellowship for the researcher. We are grateful to the Bangladesh Rice Research Institute, Rajshahi for supplying the rice seedlings and Soil Resource Development Institute (SRDI), Rajshahi for recommending the appropriate dosage of fertilizers.

\section{References}

Azad, M.A.K.; Islam, M.N.; Alam, A.; Mahmud, H.; Islam, M.A.; Karim, M.R. and Rahman, M. 2009. Arsenic uptake and phytotoxicity of T-aman rice (Oryza sativa L.) grown in the As- amended soil of Bangladesh. Environmentalist, 29:436-440.

Abedin, M.J.; Cotter-Howells, J.; Meharg, A.A. 2002. Arsenic uptake and accumulation in rice (Oryza sativa L.) irrigated with contaminated water. Plant Soil, 240:311-319.

BGS (British Geological Survey) . 2000. Executive summary of the main report of Phase I, Groundwater Studies of Arsenic Contamination in Bangladesh, by British Geological Survey and Mott MacDonald (UK) for the Government of Bangladesh, Ministry of Local Government, Rural Development and Cooperatives, Department of Public Health Engineering, and Department for International Development (UK).

BGS and DPHE. Kinniburgh DG and Smedley PL (Eds) . 2001. Arsenic contamination of groundwater in Bangladesh. British Geological Survey Technical Report WC/00/19. British Geological Survey. Keyworth, UK

Chino, M. 1981. In: Kitagishi, K. and Yamane, I. $9^{\text {th }}$ eds., Heavy metal pollution in soil of Japan, Japan Sci. Soc. pp. 65-80.

Delowar, H.K.M.; Yoshida, I; Harada, M; Sarkar, A.A; Miah, M.N.H; Razzaque, A.H.M.; Uddin, M.I.; Adhana, K. and Perveen, M.F. 2005. Growth and uptake of arsenic by rice irrigated with Ascontaminated water. J Food Agric Environ, 3:287291

Dittmar, J; Voegelin, A; Roberts, L.C.; Hug, S.J.; Saha, G.C.; Ali, M.A.; Badruzzaman.,B.M.; Kretzschmar, and R. 2007. Spatial distribution and temporal 
variability of arsenic in irrigated rice fields in Bangladesh. Environ Sci Technol, 41:5967-5972

Fran, S.R.; Horton, D. and Burdette, L. 1988. Influence of MSMA on straighthead, arsenic uptake and growth response in rice (Oryza sativa L.). Arkansas AES Rep Ser, 302:1-12

Gilmour, J.T and Wells, B.R. 1980. Residual effect of MSMA on sterility in rice cultivars. Agron. J, 72:1066-1067.

Hoque, M. A. and Ahmed, K.M. 2006. Impact of irrigation rice paddies with groundwater containing arsenic in Bangladesh. Sci Total Environ, 367:769777

Hossian, M. B.; Jahiruddin, M.; Panaullah, G.M.; Loeppert, R.H.; Islam, M.R.; Duxbury, J.M. 2008. Spatial variability of arsenic concentration in soils and plants, and its relationship with iron,manganese and phosphorus. Environ Pollut, 56:739-744

Heikens, A.; Panaullah, G. M. and Meharg, A. A. 2007. Arsenic behaviour from groundwater and soil to crops: impacts on agriculture and food safety. Rev Environ Contam Toxicol, 189:43-87

Hossain,M.B.;Jahiruddin,M.;Leoppert,R.H.;Panaullah,G .M.;Islam,M.R.;Duxbury,J.M. 2009. The effect of iron plaque and phosphorus on yield and arsenic accumulation. Plant Soil,317:167-176

Islam, M.R.; Islam, S; Jahiruddin, M. and Islam, M.A. 2004. Effects of irrigation water arsenic in the ricerice cropping system. $J$ Biol Sci ,4:542-546

Jahiruddin, M.; Islam, MA; Islam, M. R. and Islam, S. 2004. Effects of As contamination on rice crop ( Oryza sativa L). Environtropica, 1:104-110

Khan, M.A.; Islam, M.R.; Panaullah, G.M.; Duxbury, J.M.; Jahiruddin, M. and Loeppert, R.H. 2009. Fate of irrigation-water arsenic in rice soils of Bangladesh. Plant Soil.

Khan, M. A.; Islam, M.R.; Panallah,G.M.; Duxbury,J.M.; Jahiruddin,M. and Leoppert, R.H. 2010. Accumulation of arsenic in soil and rice under wetland condition in Bangladesh. Plant Soil, 333:263-274

Liu, G.L and Gao, S .D. 1987. The effect of arsenic in red soil on crops.J. Soil Sci. (China), 18:231-233.

Meharg, A.A.; Rahman, M.M. 2003. Arsenic contamination ofBangladesh paddy field soils: implications for rice contribution to arsenic consumption. Environ Sci Techno, 137:229-234
Marin ,A.R; Massecheleyn, P.H and Patrick, W.H. Jr. 1992. The influence of chemical form and concentration of arsenic on rice growth and tissue arsenic concentration. Plant Soil, 139:175-183

Milam, M.R; Marin, A; Sedberry, J.E; Bligh, D.P. and Sheppard, R. 1988. Effect of water management, arsenic, and zinc on selected agronomic traits and rice grain yield. Northeast Research Station and Macon Ridge Research Station, Baton Rouge, USA. In Annual Progress Report, pp. 105-108.

Panaullah, G.M.; Alam, T.; Hossain, M.B.; Loeppert, R.H.; Lauren, J.G.; Meisner, C.A.; Ahmed, Z.U. and Duxbury, J.M. 2009. Arsenic toxicity to rice (Oryza sativa L.) in Bangladesh. Plant Soil, 317(1):31-39

Smith, A. H.; Lingas, E. O. and Rahman, M. 2000. Contamination of drinking-water by arsenic in Bangladesh: a public health emergency. Bull WHO, 78:1093-1103

Tsutsumi, M. 1980. Intensification of arsenic toxicity to paddy rice by hydrogen sulphides and ferrous iron I. Induction of bronzing and accumulation in rice by arsenic. Soil Sci. Plant Nutr, 26:561-569.

Wang, Fu-Min.; Chen,Zhang-Liu.; Zhang, Lu.; Gao, Yan-Ling. and Sun,Yong-Xue . 2006. Arsenic uptake and accumulation in rice (Oryza sativa L.) at different growth stages following soil incorporation of roxarsone and arsanilic acid. Plant Soil, 285:359-367

World Bank. 2005. Arsenic contamination of groundwater in South and East Asian countries: Towards a more effective operational response. Report 31303 World Bank, Washington DC. 63p.

Xie, Z and Huang, C. 1994. Relatioship between lead, zinc and arsenic contents and rice tillering in the soil rice system. J. Zhejiang Agril. Univ., 20: 67-71.

Yan, W.G; Dilday, R.H; Tai, T.H; Gibbons, J.W.; McNew, R.W.; Rutger, J.N. 2005. Differential response of rice germplasm to straighthead induced by arsenic. Crop Sci, 45:1223-1228

Van, G. A.; Zheng, Y.; Cheng, Z.; He Y; Dhar, R.K.; Garnier, J.M.; Rose, J.; Seddique, A.; Hoque, M. A. and Ahmed, K.M. 2006. Impact of irrigation rice paddies with groundwater containing arsenic in Bangladesh. Sci Total Environ, 367:769-777 